\title{
WATER MANAGEMENT IN TIDAL SWAMPY AREAS FOR COCONUT CULTIVATION
}

by

\author{
Edy Sigit Sutarta*
}

\begin{abstract}
Coconut has been traditionally cultivated in tidal swampy areas by farmers for a long time. Coconut growth in this area needs a good water management system, besides fertilization. Flooding in this area not only retards coconut growth, but also reduces production. A water management system, mainly-drainage has been used by farmers depending on conditions of the area and farmer's abilities. Functions and types of water management system that have been used for coconut cultivation in tidal swampy areas are discussed.
\end{abstract}

\section{INTRODUCTION}

Increasing coconut production in Indonesia is being attempted through various eff6rts. Rehabilitating the existing gardens by efficient replanting the unproductive stands with suitable hybrids, as well as increasing the land area under coconut are some of the priority actions that are already being pursued by the government of the Republic of Indonesia (Corputty et al, 1982). Another effort is to expand coconut area to tidal swampy areas.

Emphasis of coconut development nowadays is on tidal swampy areas, because of the availability of large extents of swampy land in Indonesia. The tidal swamp area in Indonesia is estimated at more than 35 million hectares (approximately $17 \%$ of the total area) nearly 7 millions ha of this, is influenced by the ebb and flow of sea water and 5.25 millions ha of the 7 million are found in Kalimantan and Sumatera province (Soebiapradja and Koestono, 1987).

The use of the swampy land for coconut cultivation has some constraints, e.g. soil fertility variations, and bad drainage.

Tidal swampy area is characterized by low topography which result, in water-logging that hampers root aeration and root activities. This problem can be solved by using good water management systems, which is the main requirement for coconut cultivation in this land. Some of water management systems for annual crop have been reported, like "fork system" canals in Kalimantan and ITB - IPB system in Sumatera. There ate some water management systems also that have been used by coconut farmers, although they still have to be evaluated.

\section{CHARACTERISTICS OF TIDAL SWAMPY LAND}

Tidal area may be defined as the region of the sea or river basin which gets inundated by sea water during high tide; and swampy area is that portion of flat or lowland which gets inundated by rain water or with other excessive water flowing from inland (Corputty et al, 1982).

*Staff Agronomy Department \& Head of Breeding Department, Coconut Research Center, Bandar Kuala, Sumatra, Indonesia 
Tidal swampy soils consist of 3 types, i.e. alluvial soil, gley humic and organosol (LPT, 1976). Alluvial and gley humic soil located in the sea shore have higher fertility than organosol. This soil is usually used by farmers mainly for coconut cultivation. Here, coconut gives bigger contribution on farmer's income than other crops.

Tidal swampy soils vary greatly in fertility. My observation in Seruwai North Sumatera shows that coconut in alluvial soil (tidal area) has sufficient phosphate, but suffers from nitrogen and potassium deficiencies. Corputty et al (1982) reported that according to investigation carried out by University of Riau, $\mathrm{pH}$ of the soil in tidal area was very low, ranging from 3.6 to 4.6. The soil fertility in general was good, although in some regions nitrogen was below the critical level.

Peat soils, the greatest part of tidal swampy area have low fertility. This soil needs $\mathrm{N}, \mathrm{P}$ and $\mathrm{K}$ fertilizers to support plant growth. Some micro nutrient such as $\mathrm{Zn}, \mathrm{B}$, Mo and mainly $\mathrm{Cu}$ must also be given (Danoesastro, 1977).

Based on prevailing water level in the field from tidal influence, and from rainfall, Prayitno (1987) and Widjaja-Adhi (1986) divided the tidal swamps into 4 types:

- Type A: Swamps directly affected by sea tide and flood during both spring and neap tides. Water depth fluctuates as much as $2.5 \mathrm{~m}$ within 24 hours near the river during the spring tide.

- Type B: Swamps directly influenced by sea tide, but flood only during the spring tide.

- Type C: Swamps are not directly influenced by sea tide and not flooded by either the spring or neap tides. There is an indirect effect of the tides by water infiltration through the soil. Water levels are affected more by rainfall than by tide. Water table is near $(<50 \mathrm{~cm})$ soil surface.

- Type D: High land areas in the tidal swamps that are not affected by sea tides. There is no water infiltration through the soil. Water table more than $50 \mathrm{~cm}$ below soil surface.

Type A and B swamps are usually called direct tidal swamps, while type C indirect tidal swamps, and type D rainfed tidal swamps.

\section{FUNCTIONS OF WATER MANAGEMENT SYSTEM}

There are some objectives of providing good water management system, i.e. :

1. to drain away the excess water from fields

2. to control (up and down) permanent water table in the field

3. to enter sea water for transportation

4. to protect the cultivable land from tidal sea water

Coconut needs enough water for its growth, but does not like flooded condition because it retards growth and root activities. Coconut in flooded area shows symptom of stunted growth and yellowish leaves. Observations in Seruwai North Sumatera showed significant difference in growth between coconut grown in flooded area and in mineral soils which was planted in 1967 (Table 1). 
Table 1. Characteristic of coconut in the flooded and non-flooded area

\begin{tabular}{|l|c|c|}
\hline \multicolumn{1}{|c|}{ Growth parameter } & Flooded & Non-flooded \\
\hline 1. Height $(\mathrm{m})$ & 4.0 & 9.6 \\
2. Stem girth $(\mathrm{cm})$ & 82.2 & 107.6 \\
3. Number of leaves & 18 & 28 \\
4. Number of nuts/spadic & $\pm 0-2$ & $\pm 4-7$ \\
\hline
\end{tabular}

Based on that data, success of this land utilization depends greatly on good water management. Draining off the excess water must be done carefully, especially in peat soil or potential acid sulphate soil.

On dry conditions, peat soil will irreversibly shrink and it becomes a shadow-sand soil that can easily catch fire and get eroded by wind or water (LPT, 1976). Moreover, excessive drainage makes fast subsidence of soil resulting in trees falling or leaning. While in soils with pyrit mineral, excessive drainage will enhance pyrit oxidification which will increase soil acidity.

Water management system in field near sea shore is used to protect coconut cultivation from sea tide water. Nevertheless in some coconut estates, sea tide water is allowed into the field during harvest period for nut transportation.

\section{TYPES OF WATER MANAGEMENT SYSTEMS}

Traditionally, water management system is built together with coconut cultivation. Disbun Riau (1988) called this system "trio tata air" (three water management systems) shows the three important elements, i.e. dike, ditch and sluice. There are some variations of the system used by farmers depending on land condition and farmer's abilities.

Corputty et al (1986) described 3 water management systems that are being practiced in Riau and Kalimantan province, i.e. open drainage system, closed drainage system and regular dike system. Besides, we found limited open drainage system in Riau and block drainage system in North Sumatera (Sutarta, 1989; Sutarta and Sitanggang, 1989).

\section{A. Open Drainage System}

This is a simple and cheap system commonly used by many smallholders. It is only found in peat soil or swampy area, mainly along the river where soil surface is higher than the river bank. The only purpose of this system is to drain off the excess rain water coming from inland.

\section{B. Closed Drainage System}

This system needs a small, $1.0 \mathrm{~m}$ wide and $1.0 \mathrm{~m}$ high dike along the river and the main drainage bank to protect this area from high tide. This system uses the automatic sluice that will open if surface level of excess water is higher than sea water. This excess water will flow out into river or sea, but when sea water level is too high it will make the sluice gate closed, preventing the sea water entering the field. 


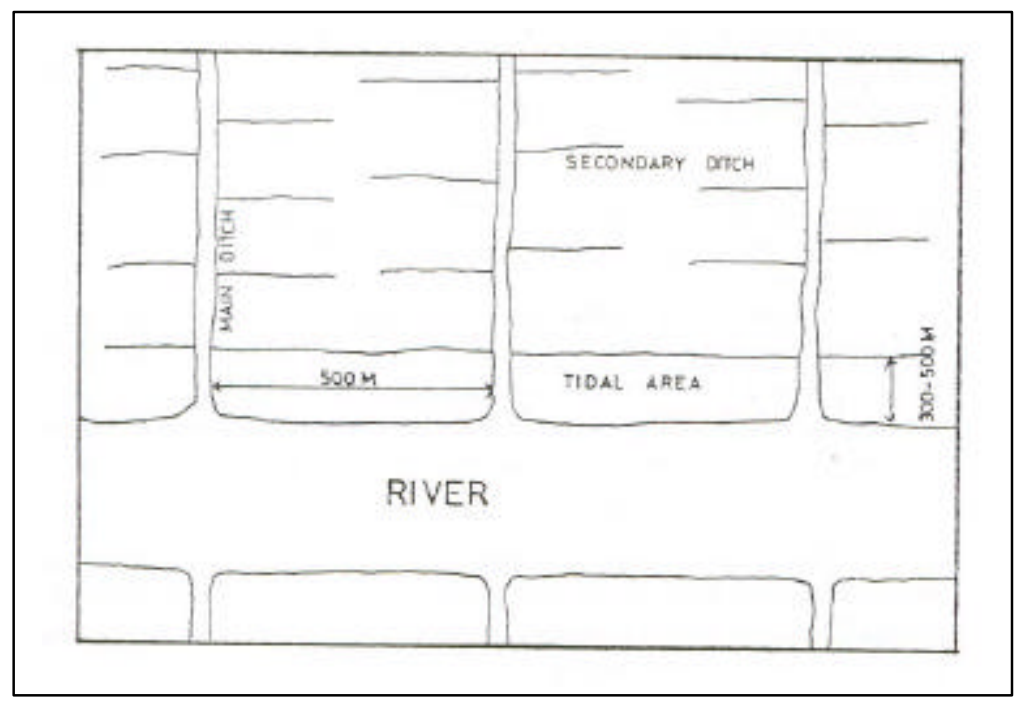

Fig. 1. Plan of simple open drainage system (Corputty, 1982)

\section{Regular Dike System}

This system requires massive dikes, $3 \mathrm{~m}$ to $5 \mathrm{~m}$ wide and $2.5 \mathrm{~m}$ gross height or $1.5 \mathrm{~m}$ net height (Fig. 3). It needs large financial backing and the use of machinery. The main drain crosses the dike through large sluice gates provided with automatic doors at a uniform distance of $500 \mathrm{~m}$ from each other.

\section{Limited open drainage system}

This system can be found far from the sea, so it is used only to drain excess water from rainfall or forest water. It is like the open drainage system, but it needs sluice gate at the end of each secondary ditch to prevent permanent surface water table in the field. It is done by regular wood-gate (Fig. 4).

Regulation of water table in the field will cause slow peat decomposition, besides providing enough water for coconut growth. Other advantage of this system is that cat clay oxidation if available can be prevented, so it will prevent soil acidification.

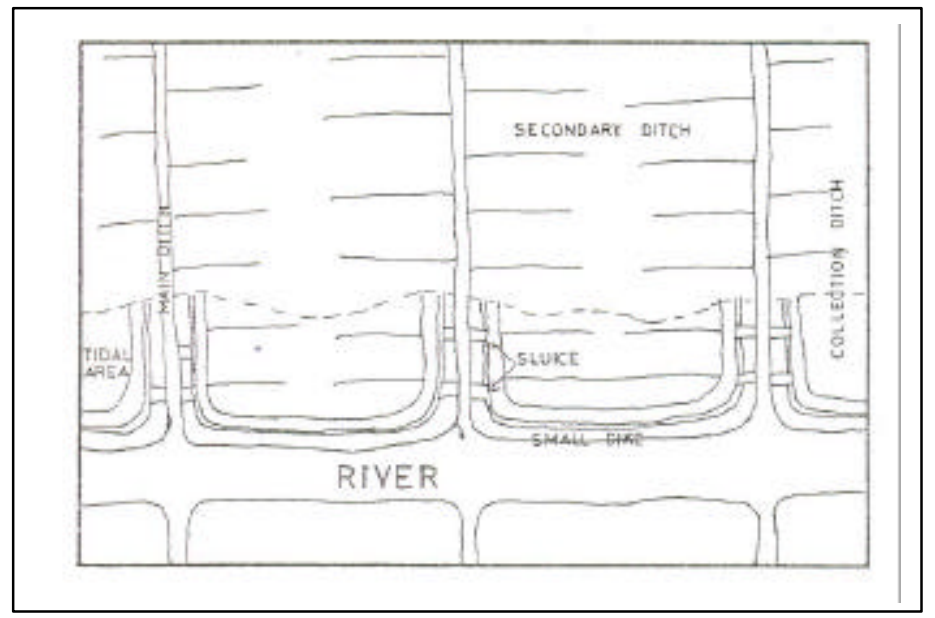

Fig. 2. Closed drainage system provided with automatic sluices (Corputty et al, 1982) 


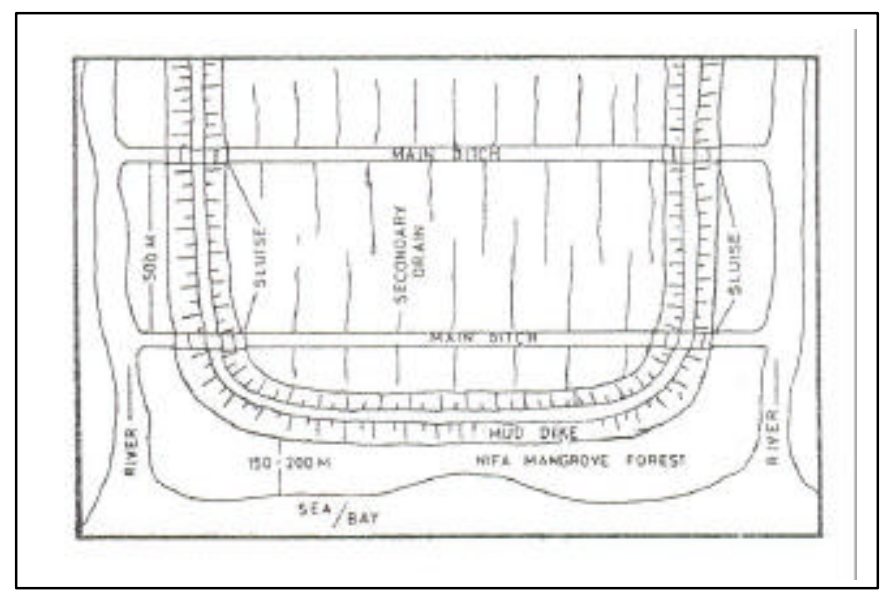

Fig. 3. Regular dike system with automatic sluice (Corputty et al, 1982)

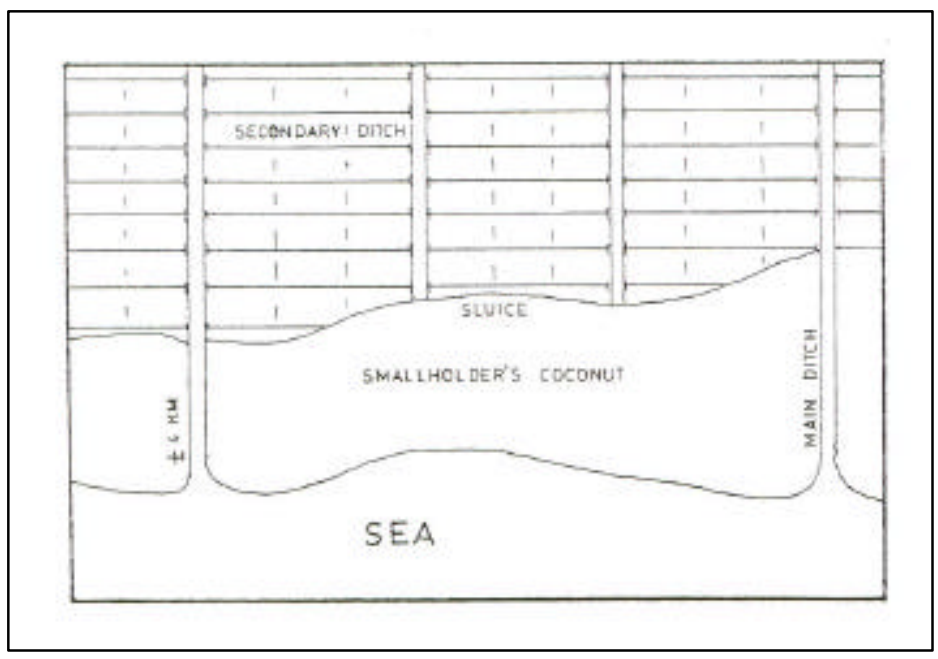

Fig. 4. Regular arrangement of limited drainage system (Sutarta and Sitanggang, 1989)

\section{E. Block Drainage System}

It is like regular dike system so that it can be used by coconut estates, specially in tidal land in North Sumatera, where each compartment or block ( \pm 25 ha) of coconut cultivation will have one water management system that can be provided by automatic sluice (Fig. 5). This sluice not only prevents sea water, but sometimes it is also used to allow sea water into certain compartment for nut transportation.

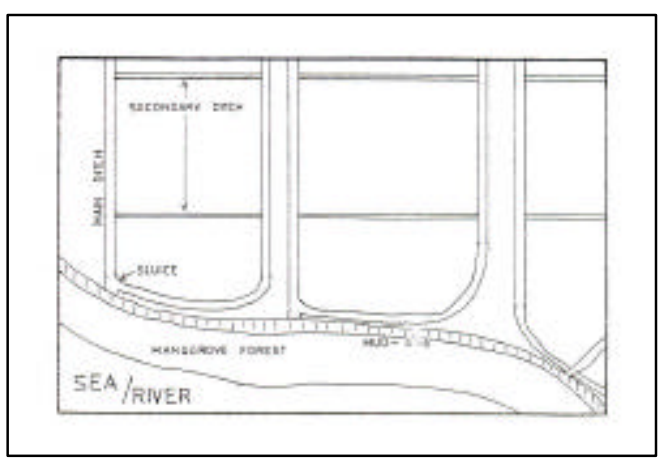

Fig. 5. Block water management system (Sutarta, 1989) 


\section{CONCLUSION}

Tidal swampy areas have high potential for coconut cultivation. Besides they have large area of the land, and a high water availability to support plant growth.

One of the main constraints of the tidal swampy land utilization is bad drainage. It can be solved by using good water management system. They are not only used to drain away excess water, but also for nut transportation and prevents the inundation of cultivable land from sea tide water.

There are 5 water management systems that have been used by farmers i.e. open drainage, closed drainage, regular dike, limited open drainage and block drainage. The best type that can be used by the farmers depend greatly on condition of the land and farmers' abilities.

\section{LITERATURE CITED}

Corputty C, S. Sulaeman, D.D. Tarigans and T.A. Davis. 1982. Growing coconuts in tidal swamps demands great effort. Ind. Agric. Res. Dev. Jour. IV (2) : 43-5 1.

Danoesastro, H. 1977. Kemungkinan pengembangan tanaman pekarangan di daerah pasang surut Kalimantan Selatan dan Kalimantan Tengah. Bulletin Test Farm P4S UGM No. 1. Yogyakarta. p: 42-69.

Disbun Riau. 1988. Keunggulan dan kelemahan tanab gambut sebagai Lahan Pengembangan Komoditi Perkebunan pada umumnya dan Kelapa Hibrida kbususnya. Riau. 19 p.

Lembaga Penelitian Tanah. 1976. Prospek Pengembangan Pertanian Daerah Pasang Surut di dalam Rangka Pembangunan Wilayah, Khususnya Daerah Perbatasan. Badan Litbang Pertanian. Bogor. 31 hal.

Prayitno, D. 1987. The role of cropping system on peatlands improvement in tidal swamp area in Indonesia. Int. Peat Soc. Symposium on Tropical Peat and Peatlands for Development. February, 9-14. Yogyakarta.

Soebiapradja, R and Koestono. 1987. Utilization of peatlands for estate crops development in Indonesia. Int. Peat Soc. Symposium on Tropical Peat and Peatlands for Development. February, 9-14. Yogyakarta.

Sutarta, ES. 1989. Sistem Tata Air Lahan Pasang Surut di Kebun Pulau Burung PT Riau Sakti United Plantations. Doc. : 33/Ill/1989. Pusat Penelitian Kelapa. Bandar Kuala. 9 p.

dan BH. Sitanggang. 1989. Laporan Kunjungan ke PT. Riau Sakti United Plantations 20-22 Pebruari 1989. Doc.: 26/111/1989. Pusat Penelitian Kelapa. Bandar Kuala. 9 p.

Widjaja-Adhi, 1. PG. 1986. Pengelolaan Lahan Pasang Surut dan Lebak. Jurnal Litbang Pertanian, V (1) : $1-9$. 